Shinji Kawahito MD,

Hiroshi Kitahata MD, Hideyuki Kimura MD, Katsuya Tanaka MD, Yoko Sakai MD, Yoshiaki Hirose MD, Shuzo Oshita MD

\section{Anaesthetic management of a patient with Williams syndrome undergoing aortoplasty for supra- valvular aortic stenosis}

Purpose: A case of a patient associated with Williams syndrome undergoing aortoplasty for supravalvular aortic stenosis is presented.

Clinical features: Williams syndrome is a rare disease associated with a characteristic facies, supravalvular aortic stenosis, and mental retardation. A 15-yr-old girl with Williams syndrome underwent aortoplasty for supravalvular aortic stenosis. Anaesthesia was induced with fentanyl and thiamylal, and maintained with nitrous oxide, oxygen, sevoflurane, and continuous intravenous infusion of fentanyl. Supravalvular aortic stenosis was evaluated using a multiplane transesophageal echocardiography (TEE) probe before and after repair.

Conclusion: Multiplane TEE was found to be very useful for anaesthetic management in a patient with Williams syndrome undergoing aortoplasty for supravalvular aortic stenosis.

Objectif : Présenter le cas d'une patiente atteinte du syndrome de Williams et Beuren devant subir une aortoplastie pour une sténose aortique supravalvulaire.

Aspects cliniques : Le syndrome de Williams et Beuren est une maladie rare associée à un faciès caractéristique, une sténose aortique supravalvulaire et un retard mental. Une jeune patiente de 15 ans atteinte du syndrome de Williams et Beuren a subi une aortoplastie pour une sténose aortique supravalvulaire. L'anesthésie a été induite avec du fentanyl et du thiamylal et maintenue avec du protoxyde d'azote, de l'oxygène, du sévoflurane et une perfusion continue de fentanyl. Avant et après la chirurgie, on a évalué la sténose aortique supravalvulaire à l'aide d'une sonde d'échocardiographie transoesophagienne (ETO) multiplan.

Conclusion : L'ETO multiplan a été jugée très utile pour la gestion de l'anesthésie chez une patiente atteinte du syndrome de Williams et Beuren qui devait subir une aortoplastie pour une sténose aortique supravalvulaire.

From the Department of Anaesthesiology, Tokushima University School of Medicine, 3-18-15 Kuramoto, Tokushima, 770-8503, Japan. Address correspondence to: Dr. Shinji Kawahito, Phone: 81-886-33-7181; Fax: 81-886-33-7182; E-mail: kawahito@clin.med. tokushima-u.ac.jp. 
W

ILLIAMS syndrome, first described by Williams et al. in 1961, ${ }^{1}$ is characterized by the triad of supravalvular aortic stenosis, mental retardation, and elfin facies. The fourth major feature of this syndrome is transient hypercalcaemia that occurs during the first year or years of life, ${ }^{2}$ and it is thought that Williams syndrome is caused by an abnormality in the metabolism of calcium and vitamin $D .{ }^{3}$ Since the incidence of this syndrome is reported to be $1: 20,000-50,000$ children, there are only a few reports regarding its anacsthetic management, ${ }^{4}$ and we are unaware of any report regarding anaesthesia for the repair of supravalvular aortic stenosis occurring typically in such patients. In the present case report, we describe an anaesthetic management of a patient with Williams syndrome undergoing aortoplasty for supravalvular aortic stenosis.

\section{Case report}

The patient was a 15-yr-old girl. Her prenatal period and delivery were uneventful. Her parents and two sisters were normal. After birth, she presented a characteristic facial structure (Figure 1) and supravalvular aortic stenosis, and she was diagnosed as Williams syn- drome. Cardiac catheterization revealed the progress of supravalvular aortic stenosis (minimum diameter, 7 $\mathrm{mm}$; the systolic pressure gradient between aorta and left ventricle, $80 \mathrm{~mm} \mathrm{Hg}$ ). Thus, she was scheduled for surgery to repair supravalvular aortic stenosis. Her growth was retarded $(140 \mathrm{~cm}, 40 \mathrm{~kg})$. In addition, mental retardation was recognized; her intelligence quotient was 51 . Blood pressure was $110 / 60 \mathrm{~mm} \mathrm{Hg}$, and heart rate was $82 \mathrm{bpm}$. Electrocardiogram and chest X-ray suggested left ventricular hypertrophy. Peripheral blood examination, including serum calcium concentration, was normal. Except for a systolic murmur (Levine III/VI) most audible in the third left interspace, no remarkable physical findings were present. She had no evidence of congestive heart failure.

On the day of surgery, the patient was premedicated with $0.3 \mathrm{mg}$ atropine and $3 \mathrm{mg}$ midazolam im 30 min before arrival at the operating theater. Anaesthesia was induced with $0.2 \mathrm{mg}$ fentanyl and $100 \mathrm{mg}$ thiamylal $i v$, and maintained with nitrous oxide, oxygen, sevoflurane, and continuous intravenous infusion of fentanyl. Muscle relaxation was obtained with vecuronium. After tracheal intubation, the left radial artery was cannulated for blood sampling and continuous
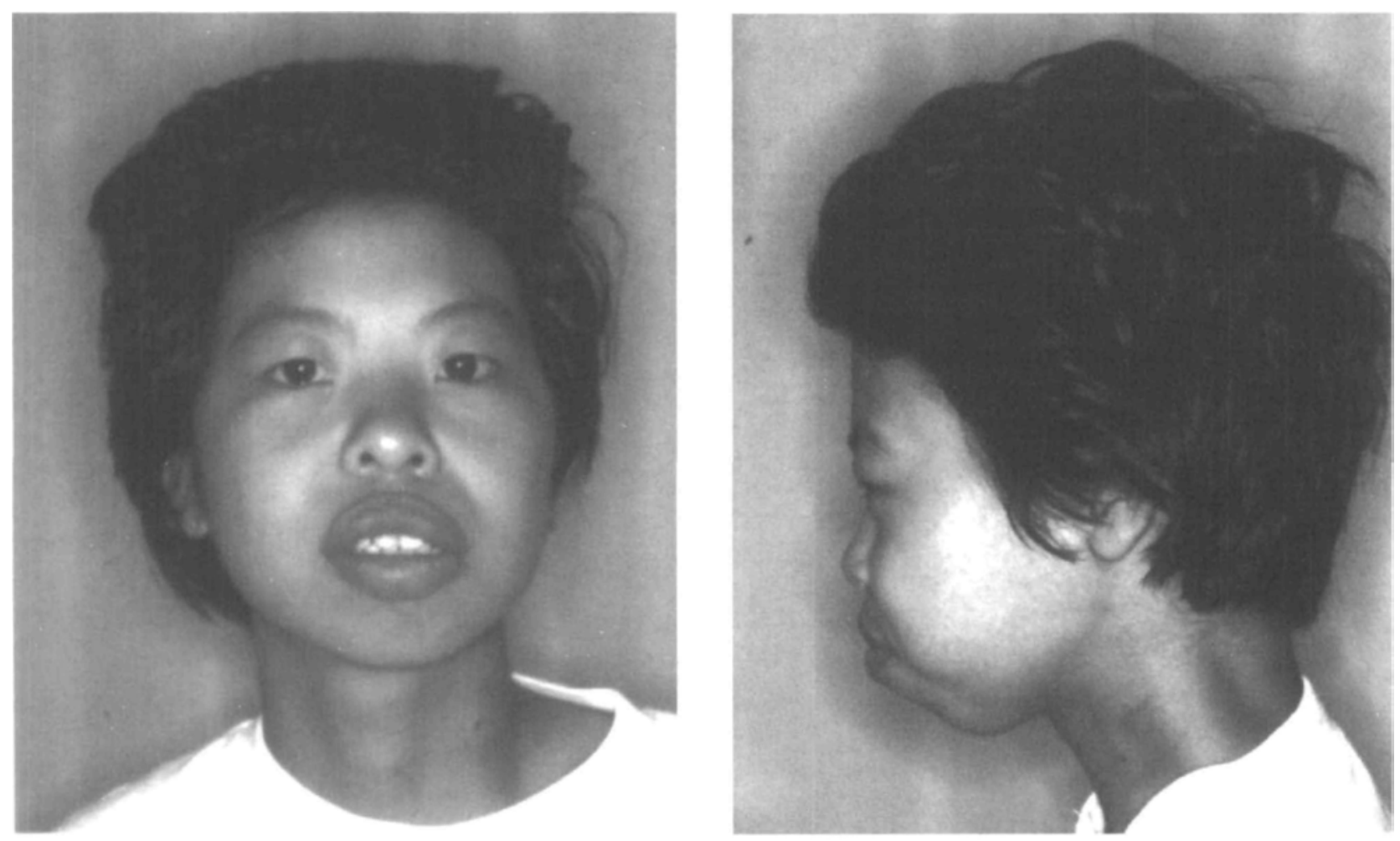

FIGURE 1 The patient with Williams syndrome. Note the high and prominent forehead, epicanthic folds, depressed nasal bridge, prominent lips with open mouth, mandibular hypoplasia, and the low set ears. The face was full, the eyes set well apart, and the checks were heavy. 

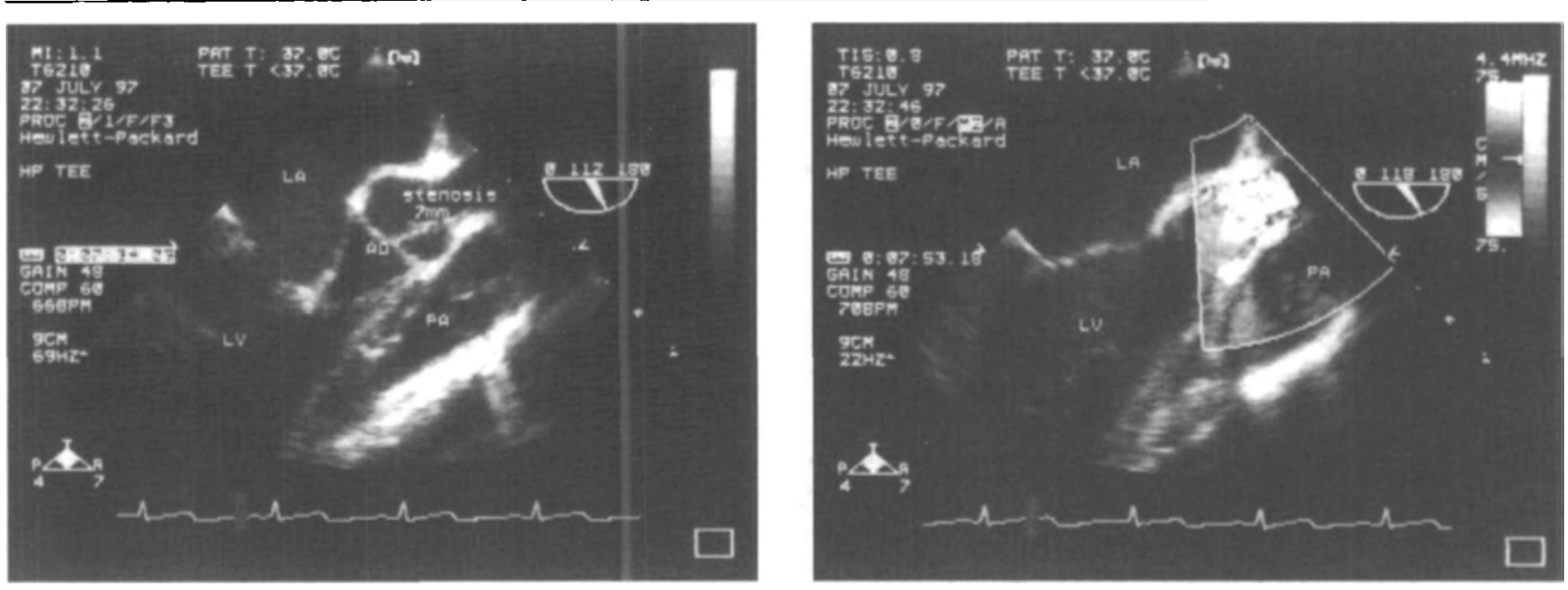

FIGURE 2 Before cardiopulmonary bypass; supravalvular aortic stenosis, demonstrated by multiplane TEE, illustrates the constriction just beyond the sinuses of valsalva (left panel). Color flow image shows the mosaic pattern (right panel).

$A O=a o r t a ; L A=l e f t$ atrium; LV=left ventricle; $P A=$ pulmonary artery; TEE=transesophageal echocardiography

monitoring of arterial pressure, and a central venous catheter was placed through the right internal jugular vein. Then a multiplane TEE probe (21369A, Hewlett Packard, Andover, MA, USA) was inserted into the oesophagus and attached to a colour Doppler imaging system (SONOS 5500, Hewlett Packard). An excellent quality image of the left ventricular outflow was recorded, and supravalvular aortic stenosis was evaluated (Figure 2 ) with multiplane TEE by rotating the probe about $120^{\circ}$ from the three chamber view. The cardiopulmonary bypass was completed using dopamine and prostagrandin El. However, immediately after completing the cardiopulmonary bypass, ST depression $(0.2 \mathrm{mV})$ in the lead II electrocardiogram and low arterial blood pressure (systolic blood pressure, $50 \mathrm{~mm} \mathrm{Hg}$ ) were recognized. Although the supravalvular aortic stenosis was repaired satisfactorily, global hypokinesis of the left ventricle was observed in the short-axis view. Since it was likely that this hypokinesis of the left ventricle was caused by compression of the coronary artery after aortoplasty, mechanical compression of the coronary artery was repaired during a second pump run. Completing the cardiopulmonary bypass was easily accomplished using dopamine, prostagrandin El, and tri-nitro-glycerin. The postoperative course was uneventful, and the trachea was extubated on the first postoperative day and she was discharged from the hospital on the 19th postoperative day.

\section{Discussion}

Among the triad of signs of Williams syndrome, the most important for the anaesthetic management is supravalvular aortic stenosis. Since myocardial oxygen consumption may be expected to increase in direct proportion to heart rate and systolic pressure load, it appears reasonable to adopt criteria for anaesthetic management similar to those applied to the more common forms of aortic stenosis. ${ }^{1}$ Thus, in the present case, special anaesthetic care was taken for management of the balance of myocardial oxygen supply and demand. That is, we prevented tachycardia, hypertension, and hypotension.

A phased array multiplane (Omni-plane) TEE probe was useful. With this instrument, the transducer array can be steered through $180^{\circ}$ from any transducer location. ${ }^{5}$ In contrast, with the conventional single-plane or bi-plane TEE instruments, excellent quality images of the left ventricle outflow cannot be obtained. Generally, the view of the left ventricle outflow, aortic valve, and ascending aorta can be seen steering the array to about $135^{\circ}$ from a three-chamber view using multiplane TEE probe. In this case, with the array at $120^{\circ}$ we could record the outflow of the left ventricle and evaluate the supravalvular aortic stenosis before and after repair.

Immediately after completing cardiopulmonary bypass, ST depression in the ECG and low arterial blood pressure were recognized. Global hypokinesis of the left ventricle was observed in a short-axis view. This hypokinesis seemed to be due to the decrease of oxygen supply by mechanical compression of the coronary artery following aortoplasty, and the increase of oxygen demand caused by left ventricular hypertrophy. In addition, it has been reported that patients suffering from Williams syndrome sometimes experience sudden 
death probably because of coronary insufficiency due to the second change in the coronary artery. Thus, early operation has been recommended. ${ }^{6}$ In the present case, the fibrous change of the coronary arterial wall and the resultant coronary insufficiency may have existed before surgery. The decompression of the coronary artery was performed during a second pump run, and completion of the cardiopulmonary bypass was accomplished successfully using tri-nitro-glycerin.

It has been reported that Williams syndrome is an autosomal dominant condition due to mutation of the elastin gene located at 7q11-23. ${ }^{7}$ Genetic studies in the present case also revealed the defect of elastin gene located at 7q11-23. In addition, genetic defects in patients with Williams syndrome are similar to those causing malignant hyperthermia. ${ }^{8}$ This is important because, as reported by Mammi $e t a l .,{ }^{8}$ patients affected with Williams syndrome may develop a malignant hyperthermia reaction to general anaesthesia.

In conclusion, in a patient with Williams syndrome, undergoing aortoplasty for supravalvular aortic stenosis, the use of multiplane TEE was beneficial in the anaesthetic management.

\section{References}

1 Williams JCP, Barratt-Boyes BG, Lowe JB. Supravalvular aortic stenosis. Circulation 1961; 24: 1311-8.

2 Black JA, Bonham Carter RE. Association between aortic stenosis and facies of severe infantile hypercalcaemia. Lancet 1963; 2: 745-8.

3 Garabédian $M$, Jacqz E, Guillozo $H$, et al. Elevated plasma 1,25-dihydroxyvitamin $\mathrm{D}$ concentrations in infants with hypercalcemia and an elfin facies. N Engl J Med 1985; 312: 948-52.

4 Patel J, Harrison MJ. Williams syndrome: masseter spasm during anaesthesia. Anaesthesia 1991; 46: 115-6.

5 Pandian NG, Hsu T-L, Schwartz SL, et al. Multiplane transesophageal echocardiography. Imaging planes, echocardiographic anatomy, and clinical experience with a prototype phased array omniplane probe. Echocardiography 1992; 9: 649-66.

6 Putnam TC, Harris PD, Bernbard WF, Gross RE. The surgical management of congenital aortic stenosis. J Thorac Cardiovasc Surg 1964; 48: 540-55.

7 Wu $Y$-Q Sutton VR, Nickerson E, et al. Delineation of the common critical region in Williams syndrome and clinical correlation of growth, heart defects, ethnicity, and parental origin. Am J Med Genet 1998; 78: 82-9.

8 Mammi I, Iles DE, Smeets D, Clementi M, Tenconi $R$. Anesthesiologic problems in Williams syndrome: the CACNL2A locus is not involved. Hum Genet 1996; 98: 317-20. 